\title{
HYPERPLASIA OF THE ADRENAL MEDULLA IN HYPERTENSION OF CHILDREN
}

\author{
BY \\ DORA BIALESTOCK \\ From the Department of Surgical Research, Royal Children's Hospital, Melbourne, Victoria, Australia
}

(RECEIVED FOR PUBLICATION MARCH 24, 1961)

Persistently high blood pressure is rare in childhood and warrants detailed investigation. Reviews on this subject by McCrory and Nash (1952) and Daeschner and Dodge (1959) have included extensive discussion of hormonal factors and adrenal tumours, but they make no mention of adrenal medullary hyperplasia.

Adrenal medullary hyperplasia was found on histological examination in two children with hypertension. In the absence of a definitive medullary tumour and with negative tests for phaeochromocytoma, hyperplasia may play an important role in the production of the hyperpiesia. The study of these two cases, and of one additional unproven case, forms the basis of this paper.

In one of these cases, G.P., microdissection techniques were used to study the nephron morphology and special histological techniques to study the juxtaglomerular body in an attempt to locate the site or origin of the renal pressor substance.

\section{Material and Methods}

To obtain perspective regarding the incidence of cases of adrenal medullary hyperplasia, case histories of all patients admitted to the Royal Children's Hospital over a seven-year period (1952-1959) and classified under hypertension without nephritis or cardiovascular disease, were studied, and subdivided on an aetiological basis. Two patients who had been investigated at the Royal Children's Hospital died, and autopsies were undertaken. These were G.P., male, aged 5 years, and F.M., male, aged 11 years. A third child, S.W., female, aged 12 years, whose clinical features fit the pattern of the two histologically proven cases died and no autopsy was performed.

The three special features which were observed histologically were the adrenal medullae, the nephrons and the juxtaglomerular apparatus of Goormaghtigh (1939). The adrenal medullae were stained with haematoxylin and eosin, the juxtaglomerular apparatus by Bowie's stain (1936) modified by Pitcock and Hartroft (1958). The nephrons were studied by the technique of microdissection (Oliver, MacDowell and Tracy, 1951; Ritchie and Waugh, 1957).
An approximate quantitative assessment of the increase in the size of the cells of the adrenal medullae was obtained by measuring 100 cells and their nuclei. The large vacuolated cells with oval eccentric nuclei were measured (Drake, Hibbard and Hellwig, 1944). Measurements from the two cases studied were compared with average measurements from three normal cases in their respective age groups. One control specimen was obtained from a case of chronic nephritis with moderate hypertension. Measurements in this case were the same as for the other two controls of the same age. No other adrenals from hypertensive children were available for study.

Pitcock's stain was used on two normal kidneys from children aged 5 years, to compare and contrast the effect of the stain with the abnormal kidneys. Nephron dissection of a comparable normal kidney from a 5-year-old child was also undertaken for comparison with observations on the abnormal.

\section{Case Reports}

Case 1.-G.P., male, aged 5 years, with adrenal medullary hyperplasia with renal disease.

Four months after his family had emigrated to Australia from Italy, G.P., a boy of 4 years, first presented at the Royal Children's Hospital, Melbourne. He was an only child, and two years before sailing for Australia, he suddenly developed a left facial paresis. This gradually improved, but was still present on his arrival in Australia. During the voyage he had been increasingly lethargic. His appetite was poor. He developed intense thirst with profuse sweats, especially at nights, when he needed two pints of fluid. He passed urine two or three times every night; there were no other urinary symptoms. There were no items of relevance in the family history.

On examination he was a small, thin, sallow boy (weight $28 \mathrm{lb}$.) with a left facial paresis and a blood pressure of $260 / 175 \mathrm{~mm}$. Hg, a large heart, with triple rhythm and systolic and diastolic bruits. His femoral pulses were easily palpable. Temperature $99 \cdot 6^{\circ} \mathrm{F}$; pulse rate 100 /minute. The liver edge was palpable; his limbs were hypotonic. The fundi were pale, but there was no papilloedema or exudate. He showed persistent variable albuminuria. Urinary concentration tests showed a variation in specific gravity from 1,015 


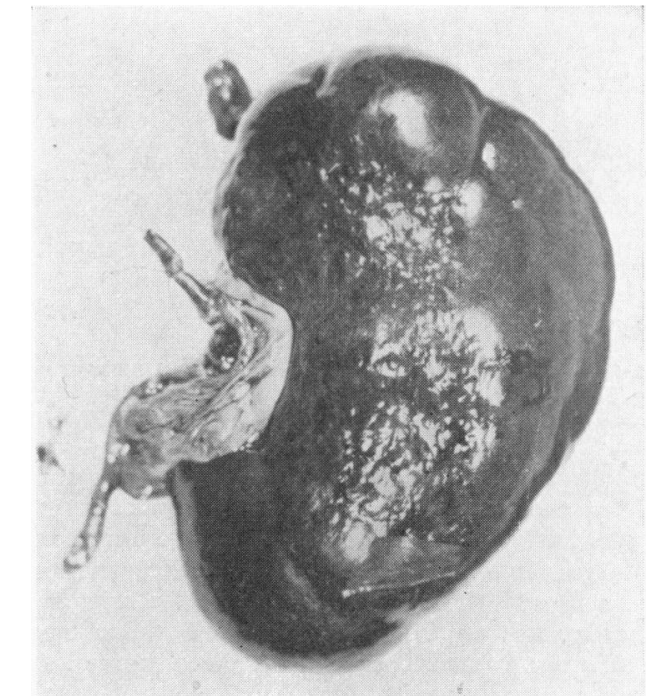

FIG. 1.-Posterior surface of right kidney of Case 1. The granular zone on this surface around the hilum was supplied by a normal calibre vessel. The rest of the kidney seen in this picture was smooth surfaced, a dusky blue and supplied by small abnormal vessels.

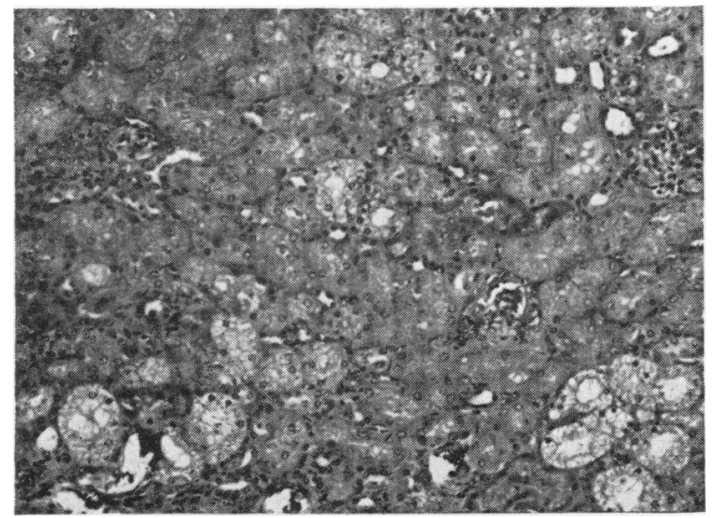

FIG. 2.-Section from the right kidney (Case 1) in the zone supplied by small abnormal vessels Note the absence of fibrosis between the nephrons. The tubular cells show severe degenerative changes. There is no cellular infiltration. $(\times 95$.)

to 1,018 . On microscopy the urine contained granular and hyaline casts but no abnormal cells. Blood urea levels fluctuated between $30 \mathrm{mg} . / 100 \mathrm{ml}$. and $60 \mathrm{mg}$./ $100 \mathrm{ml}$. Full blood examination, serum proteins and electrolyte pattern and electrophoresis pattern were all normal. Urinary pressor amine tests were normal. The intravenous pyelogram was normal. Aortography revealed renal angiograms which indicated a more rapid and dense blush on the left than on the right side. Both sides finally exhibited good renal iodide density.

While in hospital Proteus was cultured from his urine. This infection was controlled with 'furadantin' (nitrofurantoin). Twelve days later, after a short course of 'ansolysen' (pentolinium), 'serpasil' (reserpine), 'chlotride' (chlorothiazide) and nitrofurantoin his blood pressure fluctuated between $270 / 170$ and $300 / 200 \mathrm{~mm}$. $\mathrm{Hg}$.

Urinary pressor amine tests repeated three times were all normal. He was sent home on antihypertensives, diuretics and mandelix, as organisms cultured this time from his urine were insensitive to other antibiotics.

For the next three months he remained symptom free. He then developed abdominal pain, anorexia, rapid heart action and a cough. He was passing urine three or four times each night. He developed gross dyspnoea and congestive cardiac failure. His blood pressure was 285/190 mm. Hg. Urine contained protein, and Proteus was cultured. Microscopy showed granular and hyaline casts. The blood urea was $44 \mathrm{mg} . / 100 \mathrm{ml}$.

The urinary potassium excretion on normal and low potassium diets was normal. Urinary ketosteroid and corticosteroid estimations were normal. In view of the normal electrolyte pattern and normal potassium excretion, the estimation of aldosterone in the urine was considered unnecessary.

Abdominal aortogram performed via the right femoral artery, revealed a normal left renal artery and abnormally small right renal artery. The right renal outline was also smaller than the left.

Howard's test (Howard, Berthrong, Gould and Yendt, 1954) for the water and salt was marred by technical difficulties.

Mainly on the findings of the second aortogram, right nephrectomy was performed. After operation, the blood pressure fell from $300 / 170$ to $260 / 140 \mathrm{~mm}$. $\mathrm{Hg}$ in the first post-operative week. Over the next few weeks his general condition progressively deteriorated, and he developed severe epistaxis, acidosis and uraemia. The blood urea rose from $96 \mathrm{mg} . / 100 \mathrm{ml}$. in the first postoperative week to $815 \mathrm{mg} . / 100 \mathrm{ml}$. just before death four weeks later.

The right kidney (45 g.) removed at operation, was normal in shape and slightly smaller than normal in size, (normal: 65 g.). Most of the kidney was a dusky grey-blue colour and was supplied by three abnormally small branches of the anterior division of the right renal artery, each about $1 \mathrm{~mm}$. in diameter. The posterior branch of the right renal artery was normal in calibre, measuring about $3 \mathrm{~mm}$. in diameter. Two raised, coarsely granular areas of normal coloured kidney tissue lay on the posterior surface of the kidney immediately around the hilum and at the upper pole of the kidney (Fig. 1). These two parts were supplied by normal calibre vessels, one the posterior division of the right renal artery and the other, an accessory branch arising from the right suprarenal artery. There were no subcapsular adhesions. The cortico-medullary demarcation was indistinct. The renal pelvis was normal.

Histologically most of this kidney, i.e. those parts probably supplied by the extremely small calibre vessels, showed crowding of glomeruli and tubules which were normal or slightly smaller than normal in size. There was no increase of interstitial tissue and no cellular infiltration. Cell outlines were indistinct and nuclei, especially of tubule cells, were poorly defined (Fig. 2). 
No thickened arterioles were seen. The histology of these parts of the right kidney supplied by the normal calibre vessels was similar to that of the left kidney and will be described in the post-mortem report.

Autopsy. The body was that of an emaciated oliveskinned 5-year-old boy with a right nephrectomy scar.

Relevant observations included a grossly enlarged heart, with maximum thickening of the left ventricle. Lungs were congested. All other organs except the kidneys and suprarenals were macroscopically and microscopically normal, except for occasional small haemorrhages. No extrarenal chromaffin tissue could be found in the neck, the peritoneal cavity or retroperitoneal tissues.

The left kidney weighed 60 g. (Fig. 3) and was normal in size and shape, though the surface was grossly congested and mottled with deep purplish-blue areas and large pale patches. The surface was smooth and the capsule stripped with ease. Section revealed poor cortico-medullary demarcation.

Microscopic changes throughout the left kidney were the same as those in the two small areas in the right kidney. There was a gross derangement of renal pattern, with hypertrophy of tubules and some glomeruli which exhibited fibrous obliteration of Bowman's space and of the capillaries. There was a generalized increase in interstitial fibrous tissue with moderate infiltration by small round cells (Figs. 4 and 5). Both the intima and medial coats of the arterioles were grossly thickened. In some, there was complete obliteration of the lumen (Fig. 5). There was no histological evidence of renal dysplasia (Ericsson and Ivemark, 1958).

These histological features reveal a severe grade of chronic pyelonephritis and arteriolar thickening.

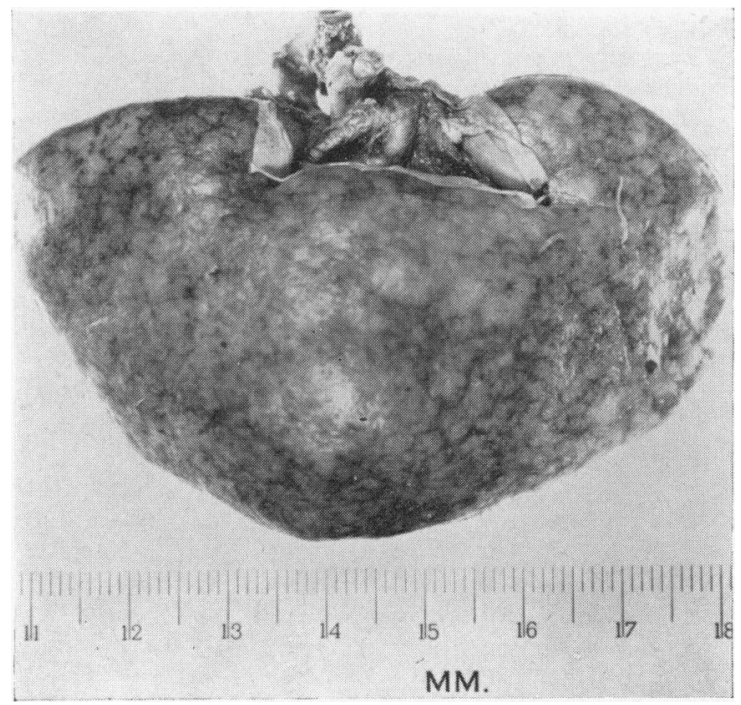

FIG. 3.-Granular mottled surface of left kidney (Case 1). This granularity was similar to that seen in those parts of the right kidney supplied by normal calibre blood vessels.

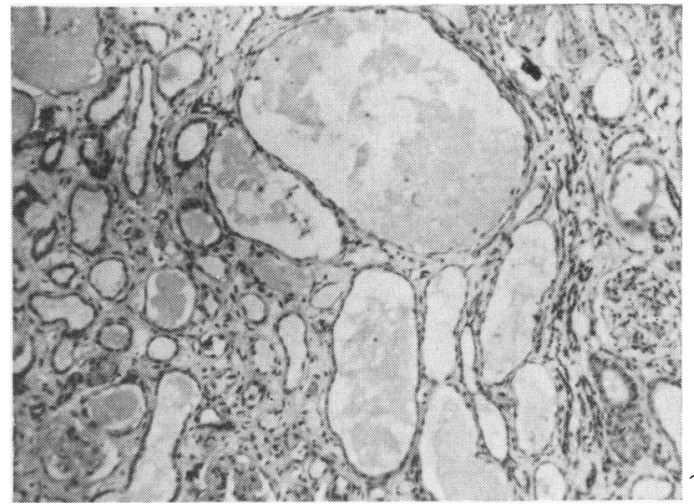

FIG. 4.-Left kidney (Case 1) gross tubular hypertrophy separated by increased fibrous tissue. These grossly hypertrophic tubules probably form the isolated cystic structures seen by the microdissection in Figs. 7 and 8. ( $\times$ 95.)

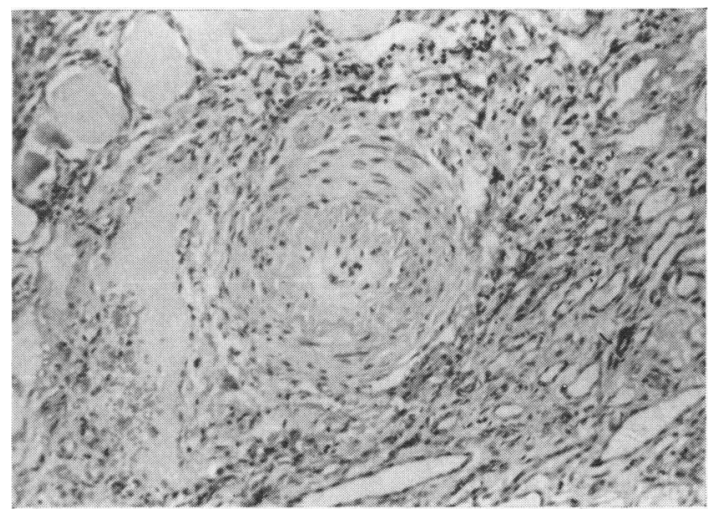

Fig. 5.-An obliterated arteriole amongst hypertrophic and atrophic tubules separated by increased fibrous tissue from the left kidney (Case 1). ( $\times$ 95.)

Microdissection was carried out on the left and right kidneys, together with dissection of a normal kidney (Table 1). Nephrons in most of the right kidney were small, but the morphology was otherwise normal. In the left kidney and those parts of the right kidney supplied by normal calibre vessels there was great variability of size of glomeruli and tubules; hypertrophic elements were more frequent than small atrophic nephrons; in this kidney a number of blind-ending cystic structures occurred predominantly in areas of dense fibrous connective tissue, probably representing parts of hypertrophic tubules sequestrated by the inflammatory process. These occurred only in areas of scarring (Figs. 6 and 7). Several times during the dissection a discrete group of cells intimately connected with the afferent arteriole at the vascular pole of the glomerulus was isolated. This probably corresponds to the juxtaglomerular apparatus of Goormaghtigh (Fig. 8).

Pitcock's stain gave a good demonstration of the cells 
TABLE 1

DIAMETER OF NEPHRONS FROM CASE 1 AND FROM NORMAL KIDNEY OF CORRESPONDING AGE

\begin{tabular}{|c|c|c|c|c|c|c|c|}
\hline \multirow{2}{*}{ Case } & & \multirow{2}{*}{$\begin{array}{c}\text { Glomerulus } \\
(\mu)\end{array}$} & \multirow{2}{*}{$\begin{array}{c}\text { Proximal } \\
\text { Tubule } \\
(\mu)\end{array}$} & \multicolumn{2}{|c|}{ Loop of Henle } & \multirow{2}{*}{$\begin{array}{l}\text { Distal } \\
\text { Tubule } \\
(\mu)\end{array}$} & \multirow{2}{*}{$\begin{array}{c}\text { Collecting } \\
\text { Tubules } \\
(\mu)\end{array}$} \\
\hline & & & & Narrow $(\mu)$ & Wide $(\mu)$ & & \\
\hline $\begin{array}{l}\text { Normal 5-year-old .. } \\
\text { Case 1: right kidney } \\
\text { Case 1: left kidney }\end{array}$ & $\begin{array}{l}\cdots \\
\cdots \\
\cdots\end{array}$ & $\begin{array}{l}150 \\
120 \\
170\end{array}$ & $\begin{array}{l}40 \\
65 \\
85\end{array}$ & $\begin{array}{l}25 \\
25 \\
\text { Not recorded }\end{array}$ & $\begin{array}{c}40 \\
40 \\
\text { Not recorded }\end{array}$ & $\begin{array}{l}40 \\
30 \\
90\end{array}$ & $\begin{array}{c}\text { Not recorded } \\
\text { Not recorded } \\
40-65 \\
\text { to } 130\end{array}$ \\
\hline
\end{tabular}

Figures obtained from average of $\mathbf{5 0}$ measurements.

of the juxtaglomerular apparatus of Goormaghtigh in all kidneys examined. These cells were seen best in association with the subcapsular glomeruli in the outer rim of the cortex. In the left kidney and those
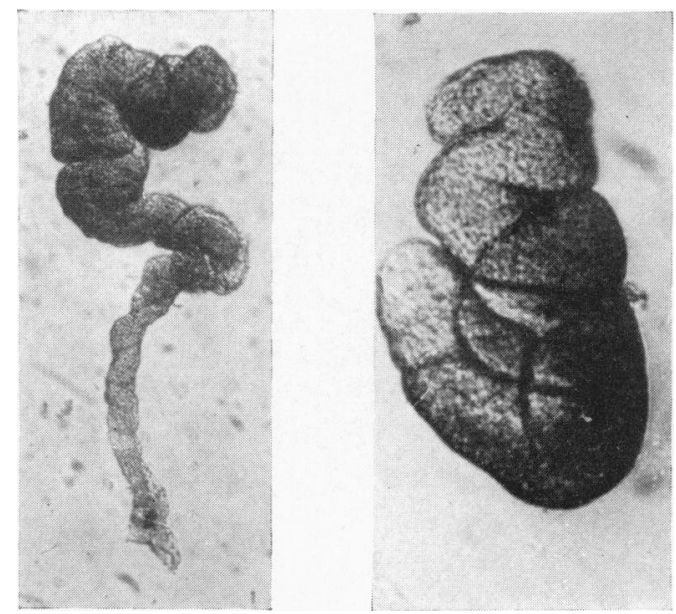

FIGS. 6 and 7.-Microdissection of the left kidney (Case 1), showing two isolated cysts terminating blindly. ( $\times$ 50.)

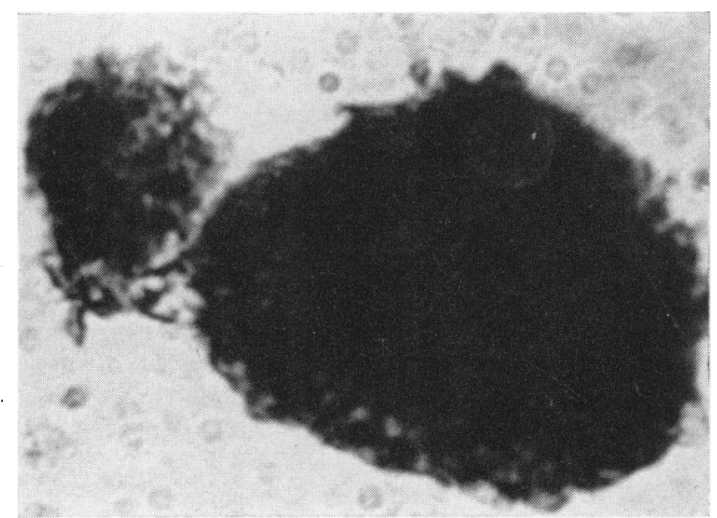

Fig. 8.-Microdissection of a glomerulus with an afferent arteriole and a group of cells attached at the upper pole. This represents an example of the juxtaglomerular apparatus in the left kidney (Case 1). ( $\times$ 550.) parts of the right kidney supplied by normal calibre vessels the juxtaglomerular cells were filled with dense basophilic granules. Granules with the same dense blue colour were also seen in the hypertrophic tubules in the same vascular distribution (Fig. 9). If, as has been suggested, these granules are the source of the renal pressor substance, then the tubule epithelium and the juxtaglomerular cells would both be involved in this case.

In summary, the two kidneys present the following features: The left kidney and those parts of the right kidney supplied by normal calibre arteries exhibit severe chronic pyelonephritis with gross thickening and obliteration of intrarenal arterioles. The juxtaglomerular apparatus is readily identified because of the dense granules in the cells. The remaining nephrons exhibit a mixture of hypertrophy and atrophy. The hypertrophic nephrons are the more numerous. The changes in the dusky right kidney were minimal. No abnormal features were found in the parenchyma apart from a very slight generalized diminution in size of the nephrons. The blood vessels were not thickened and the juxtaglomerular apparatus was identified but contained no granules.

The suprarenal glands were not weighed, but they appeared macroscopically normal.

Microscopically the cortex was normal with all zones well defined. The medulla contained far more cellular tissue than is usually observed. Sheets of cells arranged

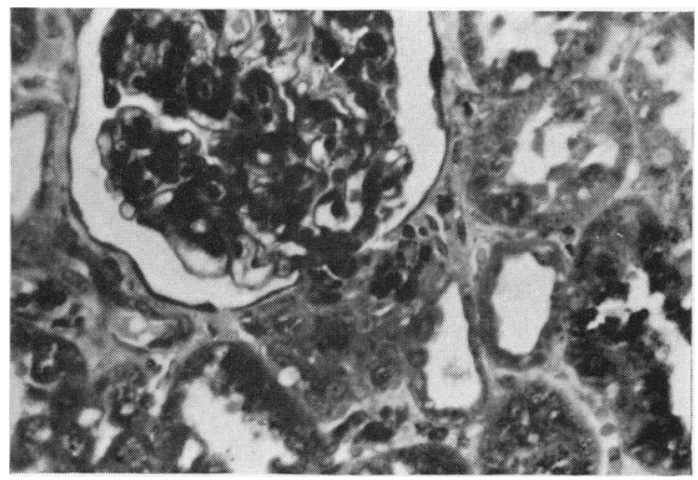

FIG. 9.-The juxtaglomerular apparatus (Pitcock's stain) seen in section in left kidney (Case 1). Dense granules can be seen in these cells, but also in the hypertrophic tubules at the right lower corner. ( $\times$ 448.) 


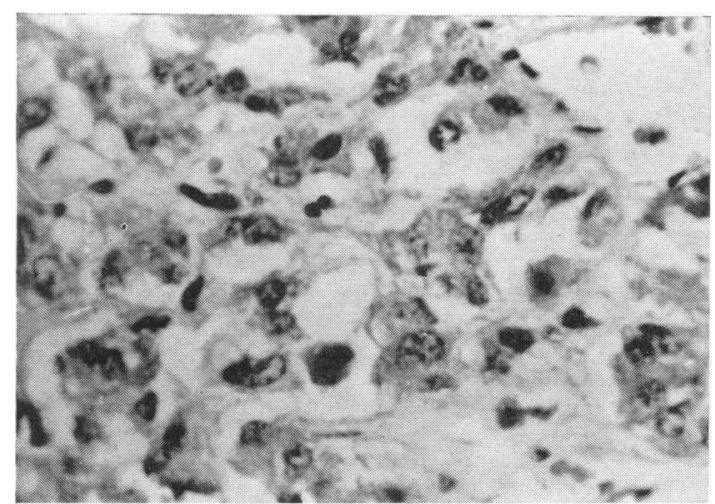

FIG. 10.-Section from the medulla (Case 1). Note the cellular pleomorphism. Most of the cells are large and oval with eccentric, pale nuclei with vacuoles and nucleoli. Note the mitotic figure at the upper right-hand side of the photomicrograph. $(\times 448$.

in cords and vesicles surrounded dilated sinusoids. Increase in bulk of the medullary tissue was due to proliferation of large vacuolated eosinophilic pleomorphic cells. Their nuclei were pale, oval, eccentrically placed, and contained nucleoli and mitotic figures (Figs. 10 and 11). One hundred such cells and their nuclei were measured. The large medullary cells in three sections from children of the same age were also measured and the average figures obtained are recorded in Table 2. The medullary cells in Case 1 were much larger than those of the controls and the nuclei were twice the normal size.

Case 2. F.M., male, aged 11 years, with adrenal medullary hyperplasia.

In this second case hyperplasia of the adrenal medulla without any other lesion was found. The child died shortly after admission, and for this reason his condition was incompletely investigated.

He had complained of numerous headaches in the past 18 months. These had become particularly severe in the week before admission to hospital. There was nothing relevant in his past history, and his family history revealed no features of relevance to this study.

Six hours before admission his headache had become worse, he had vomited, become stuporose and gradually lost consciousness.

When examined, the child was semicomatose and very restless-blood pressure $250 / 180 \mathrm{~mm}$. $\mathrm{Hg}$, femoral pulses were easily palpable and physical examination revealed no abnormality. Reflexes were all present and active, his plantar responses were extensor and his fundi exhibited papilloedema but no exudates. A ventriculogram suggested a possible block in the Aqueduct of Sylvius. Craniotomy and exploration of the posterior fossa were performed but revealed no cause for the raised intracranial pressure.

Urine was normal to ward tests and on microscopy, blood urea estimation was $43 \mathrm{mg} . / 100 \mathrm{ml}$. He died without appreciable change in his condition 19 hours after admission.

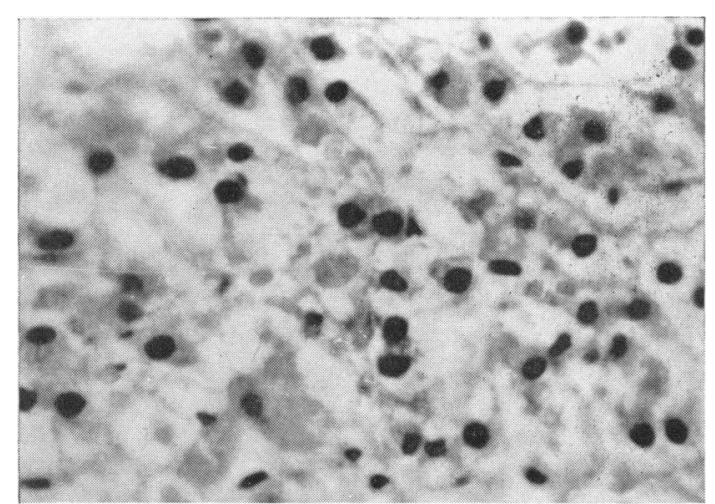

FIG. 11.-From the medulla of a 5-year-old control. The cells are far more uniform, smaller with round dark nuclei and there are no mitotic figures. $(\times 476$.

Autopsy. The heart was grossly enlarged with thickening predominantly of the wall of the left ventricle. The aqueduct was not stenosed. Apart from these features, the vascular, respiratory, digestive, reticuloendothelial and central nervous systems were normal.

The genito-urinary system was normal. Both kidneys were of normal size (right $83 \mathrm{~g}$. and left $78 \mathrm{~g}$.), their capsules stripped readily and on section the appearance was that of normal renal architecture. Pelvis, ureters and bladder were all normal in size. The bladder was thin-walled and clear urine could be expressed readily through the urethra. Histologically, glomeruli, tubules and interstitial tissues were normal. Arterioles were thickened.

A thorough search was made for extra-adrenal chromaffin tissue, but no tumour of this nature could be found. Regions examined included the entire peritoneal cavity and the retroperitoneal tissues. The neck was explored to exclude a carotid body tumour. None was found.

The adrenals each weighed $4 \mathrm{~g}$. and appeared normal to the naked eye. Other endocrine glands were macroscopically and histologically normal. Microscopically the changes in the adrenals were very similar to those described in Case 1. Cortex was normal with all layers well defined. The medulla appeared to be more cellular than usual with the increase in volume again due to

TABLE 2

MEASUREMENTS OF CELLS OF MEDULLA OF SUPRARENAL GLANDS

\begin{tabular}{|c|c|c|c|}
\hline Case & $\begin{array}{c}\text { Medullary } \\
\text { Cells } \\
(\mu)\end{array}$ & $\begin{array}{l}\text { Nuclei } \\
\text { ( } \mu)\end{array}$ & $\begin{array}{l}\text { Mitotic } \\
\text { Figures }\end{array}$ \\
\hline $\begin{array}{l}\text { Case } 1: \\
\quad \text { Age } 5 \text { years } \ldots \\
5 \text {-year-old controls (3 } \text { cases) } \ldots\end{array}$ & $\begin{array}{l}18 \\
12\end{array}$ & $\begin{array}{r}10 \\
5\end{array}$ & $\begin{array}{l}\text { Present } \\
\text { Absent }\end{array}$ \\
\hline $\begin{array}{l}\text { Case } 2: \\
\text { Age } 11 \text { years } \ldots \\
11 \text {-year-old controls }(3 \text { cases })\end{array}$ & $\begin{array}{l}16 \\
10\end{array}$ & $\begin{array}{l}9 \\
5\end{array}$ & $\begin{array}{l}\text { Absent } \\
\text { Absent }\end{array}$ \\
\hline
\end{tabular}


TABLE 3

ANALYSIS OF 20 CASES OF HYPERTENSION (GLOMERULONEPHRITIS AND CARDIOVASCULAR DISEASE EXCLUDED)

\begin{tabular}{|c|c|c|c|}
\hline Diagnosis & No. of Cases & Sex & Comment \\
\hline $\begin{array}{l}\text { Adrenal medullary hyperplasia } \\
\text { (Case } 1 \text { and Case 2) }\end{array}$ & 2 & Male & $\begin{array}{l}\text { Severe hypertension, one case with associated renal } \\
\text { disease, the other without any other lesion }\end{array}$ \\
\hline $\begin{array}{l}\text { Diagnosis uncertain, possibly medullary hyperplasia } \\
\text { (Case S.W.) }\end{array}$ & 1 & Female & $\begin{array}{l}\text { An 11-year-old girl presented with a four months' } \\
\text { history of severe headaches. Blood pressure } \\
200 / 140 \mathrm{~mm} \text {. Hg. Repeated urine microscopy } \\
\text { revealed no abnormality and concentration power } \\
\text { was up to } 1,032 ; \text { Hb normal; repeated regitine } \\
\text { tests and estimations of urinary pressor amines } \\
\text { gave normal results; one urea clearance test gave } \\
55 \% \text { of normal clearance; blood urea estimations } \\
\text { fluctuated between } 34 \mathrm{mg} . / 100 \mathrm{ml} \text {. and } 64 \mathrm{mg} . / \\
100 \mathrm{ml} \text {; an intravenous pyelogram showed normal } \\
\text { kidneys and an aortogram revealed a normal renal } \\
\text { vascular pattern. A diagnosis of chronic nephritis } \\
\text { was made. The child died at home with renal } \\
\text { failure two years later; no autopsy was performed }\end{array}$ \\
\hline Phaeochromocytoma & 3 & Male & $\begin{array}{l}\text { Severe hypertension; two cured by removal of the } \\
\text { tumour; one died of secondary deposits with } \\
\text { severe hypertension }\end{array}$ \\
\hline Unilateral renal disease & 4 & $\begin{array}{l}3 \text { male } \\
1 \text { female }\end{array}$ & $\begin{array}{l}\text { Moderate hypertension; blood pressure in the three } \\
\text { males became normal after unilateral nephrectomy; } \\
\text { in the female, the blood pressure is still moder- } \\
\text { ately raised after unilateral nephrectomy }\end{array}$ \\
\hline Renal dysplasia with obstruction & 2 & Male & Severe hypertension progressive until death \\
\hline Polyarteritis nodosa & 1 & Male & $\begin{array}{l}\text { Moderate hypertension; death in congestive cardiac } \\
\text { failure }\end{array}$ \\
\hline 'Essential' hypertension & 1 & Male & $\begin{array}{l}\text { A child with moderate hypertension; a unilateral } \\
\text { nephrectomy failed to control the blood pressure; } \\
\text { he is still under treatment five years later with } \\
\text { anti-hypertensive drugs }\end{array}$ \\
\hline Emotional hypertension and anorexia nervosa & 1 & Female & $\begin{array}{l}\text { A 12-year-old girl with moderate hypertension } \\
\text { treated with anti-hypertensive drugs for four years; } \\
\text { she developed anorexia nervosa which was treated } \\
\text { successfully four years after the onset of the } \\
\text { hypertension; the blood pressure became normal } \\
\text { and she became normotensive without drugs }\end{array}$ \\
\hline $\begin{array}{l}\text { A variety of unassociated conditions, cerebral } \\
\text { cyanosis, sagittal sinus thrombosis, anaphylac- } \\
\text { toid purpura, post-tonsillectomy haemorrhage, } \\
\text { idiopathic acrodynia }\end{array}$ & 5 & $\begin{array}{l}4 \text { male } \\
1 \text { female }\end{array}$ & $\begin{array}{l}\text { In all cases the hypertension was moderate and } \\
\text { had become normal within four weeks }\end{array}$ \\
\hline
\end{tabular}

large vacuolated eosinophilic cells and their oval nuclei. There was less pleomorphism of these cells than in Case 1 and no mitotic figures were seen.

Measurements were taken of 100 of the large cells and their nuclei and an average figure obtained. Three other adrenal medullary sections from children of the same age as Case 2 were similarly measured. One patient in the control group was hypertensive (chronic nephritis), but the measurements obtained for this child were compatible with the two normotensive controls.

The figures obtained are listed in Table 2. They reveal an increase in size of cells and nuclei similar to that observed in Case 1.

\section{Incidence of Hypertension}

In the assessment of 20 cases of hypertension seen at the Royal Children's Hospital over the seven-year period (1952-1959) only those cases without nephritis and cardiovascular disease were included.
In Table 3, the term 'moderate' hypertension is used when the systolic pressure is below $180 \mathrm{~mm} . \mathrm{Hg}$ and the diastolic below $120 \mathrm{~mm}$. Hg. The term 'severe' hypertension has been reserved for pressures above these.

\section{Discussion}

Arising from the investigations of the cases in this paper, the following points will be discussed; the male preponderance and the incidence of the cases of medullary hyperplasia in the hypertensive children, the observations favouring adrenal medullary hyperplasia as a separate entity, the position of renal factors in hypertension and the possible sites of production of the pressor substance, the complexity of hypertension in man and the place of adrenalectomy in the management of malignant hypertension. The study of the hypertensive children (Table 3) reveals a male preponderance 
of four to one; 16 of the 20 patients were boys and four were girls.

The examples of medullary hyperplasia form a clinical group the incidence of which in this analysis is comparable with that of the well-documented group of phaeochromocytoma.

The Group-Is it an Entity? The medullary cells of Cases 1 and 2 were indisputably hypertrophic. In Case 2 the medulla of the adrenals was the only pathological feature observed on autopsy which could account for the hypertension. No definite tumour tissue was demonstrated elsewhere after careful and extensive search.

Classification of S.W. (Table 2) is difficult because of lack of histological studies. All the clinical tests were negative and this case presents clinical features similar to Case 2, so perhaps the underlying cause of the hypertension was hyperplasia of the adrenal medulla. The persistent severe hypertension could have caused renal damage (Wilson and Byrom, 1939) and death in renal failure two years after the original investigations.

In the complex case (Case 1) it seems likely that the adrenal medullary hyperplasia was of primary importance as neither routine microscopy nor microdissection suggested any basic renal abnormality which could have predisposed to the development of pyelonephritis in this child (Ericsson and Ivemark, 1958; Bialestock, 1958). Kimmel (1942) examined an extensive series of children with pyelonephritis and found that only $10 \%$ showed a significant rise in blood pressure. On the other hand, experimental studies (Woods, 1958) have shown that hypertension per se can predispose to the development of pyelonephritis. Thus, in Case 1 the hypertension arising from the adrenal medullary hyperplasia could have been the primary cause of the renal damage.

These cases exhibit a pathological state of hypertrophy of the adrenal medulla. It seems reasonable to assume that the hypertrophy arises from increase in function. With the tests now in use pressor substances produced by these cells were not identified. It is postulated that medullary hyperplasia with its clinical effects on blood pressure should be regarded as a new group.

There has been of recent years a phase in management of hypertension which favoured excision of a small or abnormal kidney. Now that these patients have been scrutinized in the light of subsequent history, much doubt has been cast on this form of treatment.

Schwarz (1924) and Ask-Upmark (1929) had suggested on clinical grounds that the removal of one small kidney might benefit hypertensive children. The experiments of Goldblatt, Lynch, Hanzal and Sumerville (1934) gave stimulus to this notion and Butler (1937), Leadbetter and Burkland (1938) and Platt (1942) all reported on the beneficial effects of unilateral nephrectomy in hypertensive children.

However, Weiss and Chasis (1943), Smith (1948) and Peart (1959) are all in agreement that, in a large series, results of nephrectomy in management of hypertension have been disappointing.

As Smith (1948) has said, 'Had someone placed a clamp on the pancreatic artery before the days of Minkowski and obtained diabetes, he might well have been led to the theory, that all diabetes is due to pancreatic ischaemia or some other disturbance in the pancreatic circulation. This is, of course, not true; it is probably a very rare case in which the pancreatic circulation plays a part'. The same remarks may be applied to the Goldblatt experiment.

In Case 1 the vascular abnormality was similar to that in a Goldblatt experiment, yet removal of this kidney failed to lower the blood pressure. The remaining kidney was one with severe pyelonephritis. Observations from cases of pyelonephritis in childhood make this condition alone unlikely to be the main cause of hypertension. The hyperplasia of the adrenal medulla might have been the factor responsible for the hypertension and could have predisposed to the development of pyelonephritis.

Pressor material is undoubtedly produced by the kidney under some conditions. Goormaghtigh (1945), Dunihue (1941) and Demopoulos, Kaley and Zweifach (1960) have postulated that the site of production of this pressor material is the granules in the cells of the juxtaglomerular apparatus. Friedman and Kaplan (1943) and Des Prez (1948), on the other hand, maintain that the epithelium of the proximal tubule is the more important site of formation of pressor substance.

In Case 1 the stain for the juxtaglomerular cells of Goormaghtigh revealed that there was an increase in granularity of these cells in the left kidney and in those parts of the right kidney which were supplied by the normal calibre blood vessels. However, hypertrophic tubules in the same vascular distribution also contained similar blue granules. If the granules characterize cells which liberate the pressor substance then these observations indicate that in Case 1 both the juxtaglomerular bodies and the tubules might be involved in the formation of pressor substance.

The studies on the three cases, Case 1 , Case 2 and S.W., make it unlikely that local renal factors were the only causes of the hypertension, so that 
we have to look further. Hyperplasia of the adrenal medullary cells which was an outstanding feature of two of these patients is a likely primary cause.

Complexity of Hypertension. In man the mechanism of hypertension is probably extremely complex. There is little doubt that renal and adrenal factors can play a part in clinical hypertension. Wilson's (1953) experiments have indicated that the normal kidney can inactivate adrenal pressor substances. $\mathrm{He}$ has suggested that kidneys and adrenals form part of a homeostatic mechanism, which, through control of tissue electrolytes, maintains the arteriolar tone.

Peart's (1959) report on the variation in response to renal transplantation in two sets of identical twins illustrates the complexity of the situation in man. In one twin the blood pressure fell to normal as soon as the transplanted kidneys commenced to function; in the other twin the blood pressure did not fall until the diseased kidney had been removed. He concluded that the pressor substance was formed in the kidney in the second case but not in the first.

Pickering, Wright and Heptinstall (1952) in a small group of children with bilateral renal disease, with one kidney smaller than the other, failed to control the hypertension after nephrectomy of the smaller kidney. After subtotal adrenalectomy, however, the blood pressure could be kept under control and the children were growing and developing normally up to six years after operation.

Studies on the incidence of adrenal medullary changes in hypertension have been made from adult material. Drake et al. (1944) reported a high incidence of hyperplasia of adrenal medullary cells in hypertension, while Sommers (1959), with a much larger series, did not support Drake's observations. Sommers reported on the changes seen in adrenals of 97 hypertensive patients. In $80 \%$ of these the adrenals were histologically normal. Cortical adenomas and phaeochromocytomas are discussed. He makes no mention of simple hyperplasia of adrenal medullary cells. It seems likely that hyperplasia is a phenomenon exhibited by hypertensive children, that the condition is uncommon, and that it should be suspected when all clinical tests have proved unrewarding.

Hormonal factors in relation to hypertension may be still more complex than those of the adrenal and kidney components, as, in three cases described by Schroeder (1953), even after adrenalectomy, the blood pressure failed to fall to normal, and it has been suggested that other endocrine organs, e.g. pituitary, are probably disturbed in these cases.

Several authors (Thorn, Harrison, Merrill, Crisci- tiello, Frawley and Finkenstaedt, 1952; Bowers, 1954; van T'Hoff, 1957) have reported encouraging results in the management of malignant hypertension with bilateral adrenalectomy.

If it can be shown by adrenal biopsy that the adrenal medulla is hyperplastic, as in the specific cases described in this paper, adrenalectomy and substitution therapy may be the logical form of treatment.

\section{Conclusions}

Clinical details are given from two children who died with severe hypertension. In both specimens hyperplasia of the adrenal medulla was found.

In one case medullary hyperplasia of the adrenal gland was the only lesion, whilst in the other pyelonephritis was present also.

Medullary hyperplasia should be considered as a disease entity for two reasons: $(a)$ in one of the patients, this was the only lesion found at autopsy to account for the hypertension, and $(b)$ because the hypertension persisted after excision of the ischaemic kidney in the second case.

There were two proven cases and one suspected case of medullary hyperplasia in a series of 20 patients exhibiting hypertension (excluding cardiovascular disease and glomerulonephritis).

In Case 1 the study of the nephrons by means of microdissection failed to reveal nephron abnormalities which might predispose to development of pyelonephritis. It could be that the hypertension of adrenal origin could have been the predisposing factor in the development of the pyelonephritis in this child.

Study of the juxtaglomerular apparatus of Goormaghtigh indicated that pressor substance is probably formed in both the juxtaglomerular bodies and in hypertrophic tubules.

I wish to thank the Senior Medical Staff of the Royal Children's Hospital, Melbourne, for access to case records, and Dr. A. L. Williams, Director of the Pathology Department, for help with the autopsy reports and criticism in the preparation of the paper.

\section{REFERENCES}

Ask-Upmark, E. (1929). Ưber juvenile maligne Nephrosklerose und ihr Verhältnis zu Störungen in der Nierenentwicklung. Acta path. microbiol. scand., 6, 383.

Bialestock, D. (1958). Microdissection study of nephrons and cysts from an infant with pyelonephritis. Aust. Ann. Med., 7, 93 .

Bowers, R. F. (1954). Bilateral adrenalectomy for severe hypertension. J. Amer. med. Ass., 154, 394.

Bowie, D. J. (1936). Method for staining pepsinogen granules in gastric glands. Anat. Rec., 64, 357.

Butler, A. M. (1937). Chronic pyelonephritis and arterial hypertension. J. clin. Invest., 16, 889.

Daeschner, C. W. and Dodge, W. F. (1959). B. Special problems in the therapy of hypertension. Treatment of hypertension in childhood with and without renal disease. In Hypertension: The First Hahnemann Symposium on Hypertensive Disease, ed. J. H. Moyer, p. 601. Saunders, Philadelphia. 
Demopoulos, H., Kaley, G. and Zweifach, B. W. (1960). The histologic distribution of renin in the kidneys of the rat and rabbit. Amer. J. Path., 37, 443.

Des Prez, J., Jr. (1948). The juxtaglomerular apparatus of the D hypertensive kidney. Amer. J. clin. Path., 18, 953.

rake, R. L., Hibbard, J. S. and Hellwig, C. A. (1944). The adrenal medulla in various diseases. A histophysiologic study. Arch. Path. (Chicago), 37, 351.

Dunihue, F. W. (1941). Effect of cellophane perinephritis on the granular cells of the juxtaglomerular apparatus. Ibid. 32, 211

Ericsson, N. O. and Ivemark, B. I. (1958). Renal dysplasia and pyelonephritis in infants and children. Part I and II. A.M.A. Arch. Path., 66, 255, 264

Friedman, M. and Kaplan, A. (1943). Studies concerning the site of renin formation in the kidney; IV. The renin content of the mammalian kidney following specific necrosis of proximal convoluted tubular epithelium. $J$. exp. Med. 77, 65.

Goldblatt, H., Lynch, J., Hanzal, R. F. and Sumerville, W. W. (1934) Studies on experimental hypertension. I. The production of persistent elevation of systolic blood pressure by means of renal ischemia. Ibid., 59, 347.

Goormaghtigh, N. (1939). Existence of an endocrine gland in the media of the renal arterioles. Proc. Soc. exp. Biol. (N.Y.) 42, 688.

(1945). Facts in favour of an endocrine function of the renal arterioles. J. Path. Bact., 57, 392

Howard, John E., Berthrong, M. Gould, D. M. and Yendt, E. R (1954). Hypertension resulting from unilateral renal vascular disease and its relief by nephrectomy. Johns Hopk. Hosp. Bull. 94, 51 .

Kimmel, G. C. (1942). Hypertension and pyelonephritis of children. Amer. J. Dis. Child., 63, 60

Leadbetter, W. F. and Burkland, C. E. (1938). Hypertension in unilateral renal disease. J. Urol. (Baltimore), 39, 611.

McCrory, W. W. and Nash, F. W. (1952). Hypertension in children: A review. Amer. J. med. Sci., 223, 671.

Oliver, J., MacDowell, M. and Tracy, A. (1951). The pathogenesis of acute renal failure associated with traumatic and toxic injury. Renal ischemia, nephrotoxic damage and the ischemuric episode. J. clin. Invest., 30, 1307.
Peart, W. S. (1959). Hypertension and the kidney. I. Clinical, pathological and functional disorders, especially in man. Brit. med. J., 2, 1353 .

Pickering, G. W., Wright, A. D. and Heptinstall, R. H. (1952) The reversibility of malignant hypertension. Lancet, $2,952$.

Pitcock, J. A. and Hartroft, P. M. (1958). The juxtaglomerular cells in man and their relationship to the level of plasma sodium and to the zona glomerulosa of the adrenal cortex. Amer. and to the zona
$J$. Path., 34, 863 .

Platt, R. (1942). Unilateral renal disease and hypertension. Proc. roy. Soc. Med., 35, 317.

Ritchie, S. and Waugh, D. (1957). The pathology of ArmanniEbstein diabetic nephropathy. Amer. J. Path., 33, 1035.

Schroeder, H. A. (1953). Hypertensive Diseases-Causes and Control, p. 327. Lea and Febiger, Philadelphia.

Schwarz, H. (1924). Kidney diseases in infants and children. II Malignant hypertension nephritis; primary sclerotic kidney (schrumpfniere). Amer. J. Dis. Child., 27, 233.

Smith, H. W. (1948). Hypertension and urologic disease. Amer. J. Med., 4, 724 .

Sommers, S. C. (1959). In Hypertension: The First Hahnemann Symposium on Hypertensive Disease, ed. J. H. Moyer, p. 22 Saunders, Philadelphia.

Thorn, G. W., Harrison, J. H., Merrill, J. P., Criscitiello, M. G. Frawley, T. F. and Finkenstaedt, J. T. (1952). Clinical studies on bilateral complete adrenalectomy in patients with severe hypertensive vascular disease. Ann. intern. Med., 37, 972.

van T'Hoff, W. (1957). Total adrenalectomy for malignant hypertension. Quart. J. Med., 26, 149.

Weiss, E. and Chasis, H. (1943). Failure of nephrectomy to influence hypertension in unilateral kidney disease. J. Amer. med. Ass., 123, 277.

Wilson, C. (1953). Renal factors in the production of hypertension, Part I and II. Lancet, 2, 579, 632 .

and Byrom, F. B. (1939). Renal changes in malignant hypertension-experimental evidence. Ibid., 1, 136.

Woods, J. W. (1958). Susceptibility of rats with hormonal hypertension to experimental pyelonephritis. J. clin. Invest., 37, 1686. 